\title{
The Last Leap of Vere Gordon Childe: His Final Days
}

$\begin{aligned} \text { Authors: } & \text { Robert Kaplan } \\ \text { Submitted: } & \text { 11. October } 2021 \\ \text { Published: } & 18 . \text { October } 2021 \\ \text { Volume: } & 8 \\ \text { Issue: } & 4 \\ \text { Affiliation: } & \text { University of Wollongong, Australia } \\ \text { Languages: } & \text { English } \\ \text { Keywords: } & \text { Vere Gordon Childe, Prehistory, Australia, Archaeology, } \\ & \text { Abercromby Professor of Archaeology, Institute of Archaeology } \\ \text { Categories: } & \text { Humanities, Social Sciences and Law } \\ \text { DOI: } & 10.17160 / \text { josha.8.4.784 }\end{aligned}$

\section{Abstract:}

Vere Gordon Childe, aged 65, the leading prehistorian of his day, died in a fall off Govetts Leap in the Blue Mountains of Australia. The manner of his death divided people. Those in contact with him during the five months of his return to Australia from the UK agreed with the coroner that the fall was accidental. He had been cheerful, friendly, optimistic and had plans to study the geology of the Blue Mountains. His colleagues in the UK, having been told that he intended to jump off a cliff when he got to Australia, took the view that he had committed suicide, attributing it the absence of a close relationship and believing that his intellectual work had come to an end. After a hiatus of several decades, there was renewed interest in Childe's work. Even though many of his ideas had not stood the test of time and his Marxist interpretations were debunked, his role in establishing prehistory as a discipline was acknowledged. This article examines the circumstances surrounding Childe's death and factors that may have contributed to his suicide. There is compelling evidence that he became depressed and returned to Australia with the intention of ending his life. Having come to terms with the decision, he was able to put on a good front for those around him.

\section{JOSHA Jumna os semene. Humanities and Arts}




\title{
The Last Leap of Vere Gordon Childe: His Final Days
}

\author{
Robert M. Kaplan
}

Clinical Associate Professor, Graduate School of Medicine, University of Wollongong, Wollongong, Australia

\section{Key Words:}

Vere Gordon Childe, Prehistory, Australia, Archaeology, Abercromby Professor of Archaeology, Institute of Archaeology

\section{Abstract}

Vere Gordon Childe, aged 65, the leading prehistorian of his day, died in a fall off Govetts Leap in the Blue Mountains of Australia. The manner of his death divided people. Those in contact with him during the five months of his return to Australia from the UK agreed with the coroner that the fall was accidental. He had been cheerful, friendly, optimistic and had plans to study the geology of the Blue Mountains.

His colleagues in the UK, having been told that he intended to jump off a cliff when he got to Australia, took the view that he had committed suicide, attributing it the absence of a close relationship and believing that his intellectual work had come to an end.

After a hiatus of several decades, there was renewed interest in Childe's work. Even though many of his ideas had not stood the test of time and his Marxist interpretations were debunked, his role in establishing prehistory as a discipline was acknowledged.

This article examines the circumstances surrounding Childe's death and factors that may have contributed to his suicide. There is compelling evidence that he became depressed and returned to Australia with the intention of ending his life. Having come to terms with the decision, he was able to put on a good front for those around him. 
In creating ideas that are thus accepted, any mortal member of Society attains immortality - yes, though his name be forgotten as completely as his bodily form dissolve. Personally I desire no more.

Vere Gordon Childe ${ }^{1}$

Better pass boldly into that other world, in the full glory of some passion, than fade and wither dismally with age.

James Joyce: The Dead

${ }^{1}$ Childe, V.G. (1956) Society and Knowledge. New York: Harper and Brothers. 
On 19 October 1957 a man with everything and nothing in mind took a walk on Govetts Leap in the Blue Mountains. ${ }^{2}$ With meticulous care, he placed his coat, compass, pipe and spectacles on a rock before tumbling off the cliff to the infinity below. $^{3}$ In this fashion ended the life of Vere Gordon (usually known as Gordon) Childe, Australia's greatest archaeologist, the leading prehistorian of his day, Marxist theorist and prolific author - ended in material form, but not in legend, myth and influence. ${ }^{4}$

The Sydney Daily Telegraph and the Sydney Morning Herald ran the police view that mislaid spectacles caused him to fall to his death; one paper reporting 'People who knew Professor Childe said that without his spectacles he was almost blind, except for looking at close objects.'

Childe made no provisions for his death or burial. The funeral on 23 October 1957, organised by his cousin Alexander Gordon and H V Evatt at St Thomas' Church in North Sydney, attracted 60 mourners. ${ }^{5}$ The ashes were kept at the Northern Suburbs Crematorium, his name added to memorial plaque NT451A belonging to the Shannon family - a distant connection to his cousin. ${ }^{6}$ Childe's will, dated 2

\footnotetext{
2 (Green 1981:154)

${ }^{3}$ Anonymous Archaeologist crashes down cliff to death. Canberra Times, 21 October 1957, 1.

${ }^{4}$ Derricourt R. The making of a radical archaeologist: The early years of Vere Gordon Childe. Australian Archaeology. December 2014, Volume 79:54-64

${ }^{5}$ Sydney Morning Herald 21 October 1957:1, 24 October 1957:13

${ }^{6}$ Barton, H. (2000). In memoriam V. Gordon Childe. Antiquity, 74(286), 769-.
} 
February 1953, left his estate to the London Institute of Archaeology with provision for the care of his sister during her lifetime. ${ }^{7}$

The state does not want deaths that do not occur in the natural course of events to remain unanswered and, as required by statute, a coroner's hearing was held. The findings did not follow the consensus. The impersonal coronial language stated that the Deceased V Gordon Childe had fallen while collecting rocks and the official cause of death was mishap. ${ }^{8}$

How had this finding been reached? Would it not be better for all if it were declared an unfortunate accident and leave it at that? Even at official level, there was a profound distaste for suicide and, in this case, the deceased was a world famous figure, even if in zones that most Australians regarded as antithetical: the intellect and socialism.

In the minds of those - and there were many - who followed Childe's career, that wrapped it up. His death attracted the highest praise for his work in prehistory, archaeology and anthropology: he was described as the world's greatest prehistorian, the most outstanding and influential figure in the discipline. Childe took archaeology from an upper-class antiquarian activity to a professional discipline. ${ }^{9}$ His writing influenced two generations of the public's understanding of the human

\footnotetext{
${ }^{7}$ Derricourt R. ibid.

${ }^{8}$ Barton, H. (2000). Ibid.

${ }^{9}$ William Joseph Peace. The enigmatic career of Vere Gordon Childe: A peculiar and individual manifestation of the human spirit. PhD Thesis. Columbia University, 1992
} 
past, alongside the academic interpretation and teaching of prehistory, while his work stimulated more professional conferences and critiques than any other in the discipline. ${ }^{10}$ Brian Fitzpatrick stated that he had gained an eminence reached only by his fellow countrymen Gilbert Murray and Samuel Alexander. ${ }^{11}$ John Morris, editor of Past and Present, called Childe the most significant archaeologist of his day whose teaching permanently changed the way mankind thinks about prehistory. A historian and scientist, he studied the behaviour of men known only through the objects they left behind them, not merely the objects themselves. All of this was done through a special lens: he was a Marxist and proud of it. ${ }^{12}$

Such were Childe's achievements that these comments were no understatement.

At the other end to his death, Childe's arrival into the world did not give any indication of the achievements to come. The son of a pedantic and strict minister, it was not a happy childhood. His beloved mother died when he was 18 , a severe loss. His father remarried and home life did not become any more amenable. The escape for Childe was to wander the bush, rocks and skies of the Blue Mountains, delighting in every plant, bird, insect and macropod. From the start, his intellect was brilliant. He did classics at Sydney University and won a scholarship to Oxford. By

\footnotetext{
${ }^{10}$ Derricourt R. ibid.

${ }^{11}$ Fitzpatrick B. Meanjin, December 1957, page 424.

${ }^{12}$ Morris J. Gordon Childe. Past and Present, No. 12 (Nov., 1957), p. 2.
} 
the time of he got there, he was a committed Marxist and shared his credo with Rajani Palme Dutt who was to be a friend for life. ${ }^{13}$

His attempt to work in state politics ('a sentimental excursion') ended in failure, confirming his cynicism about Australian labour, to which he responded by joining the International Workers of the World (the Wobblies) and gave the first indication of his intellectual range by writing How Labour Governs (1923), the first analysis of parliamentary socialism in action. ${ }^{14} \mathrm{He}$ applied Marxist theories to his work, but never joined the party and was later to be very critical of Soviet archaeology. This did not allay the red stigma which followed him through his career and even got him banned from entering the USA in the fifties. ${ }^{15}$

In 1927, Childe gained the post of Abercromby Professor of Archaeology at University of Edinburgh ${ }^{16}$ and, despite his reluctance, embarked on the digs for which he became famous: Skara Brae, Earn's Hugh, Larriban, Finavon, Rahoy and Rinyo. In 1946, he left Edinburgh with some relief to take up the position as director and professor of European prehistory at the Institute of Archaeology, pleased to

${ }^{13}$ Sherratt A. V. Gordon Childe: Archaeology and Intellectual History. Past \& Present, No. 125 (Nov., 1989), pp. 151-185.

${ }^{14}$ V. G. Childe. How Labour Governs: A Study of Workers' Representation in Australia. London, 1923.

${ }^{15}$ Anonymous. Skara Brae archaeologist was MI5 target; New research throws light on why Scottish establishment tried to freeze out Vere Gordon Childe from top job. Sunday Times, London, England, 17 Dec. 2017, p. 13.

${ }^{16}$ Editorial. Antiquity, March 1959, pge 2. 
return to London. ${ }^{17} \mathrm{~A}$ decisive figure in the move from antiquarianism, Childe launched archaeology into a social science by investigating fundamental issues: the origin of farming, the relation of environmental and social change, and how the first cities and states emerged. ${ }^{18}$ Intrinsic to this was the spread of Indo-European languages and people bringing Near Eastern civilizations into Europe.

Childe was a proponent of the culture-historical approach to archaeology, integrating local research with the broad picture of European and Near Eastern prehistory. The Dawn of European Civilisation (1925) was a unique demonstration of the role of archaeology in European prehistory. ${ }^{19}$ His book Progress in Archaeology was extremely influential. ${ }^{20}$ Childe sought a system of social behaviour which accorded with the known facts of prehistory. ${ }^{21}$ His aim was to show the 'scientific' nature of history (a preoccupation of Marxists) and justify archaeology as an historical discipline. Known as the "Great Synthesizer", he focussed on cultural evolution, rather than field work, which he did reluctantly but meticulously. Some of his ideas were a product of the time, when there was little of the technology we now

\footnotetext{
${ }^{17}$ Harris DR. 'A new professor of a somewhat obscure subject': V. Gordon Childe at the London Institute of Archaeology, 1946-1956. European Journal of Archaeology Vol. 12(1-3): 123-144 .

${ }^{18}$ Yoffee N, Fowles S. Archaeology in the Humanities. Diogenes 58(1-2) 35-52.

${ }^{19}$ V. Gordon Childe. The Dawn of European Civilization [The History of Civilization, edited by C. K. Ogden\}. New York, Alfred A. Knopf. 1925.

${ }^{20} \mathrm{~V}$ Gordon Childe. Progress in Archaeology. London : Watts, 1944.

${ }^{21}$ Ravetz A. Notes on the Work of V. Gordon Childe. The New Reasoner, Autumn 1959 number 10, 56-66.
} 
take for granted, such as carbon dating; his Marxist theorising put off many but did not detract from his influence. ${ }^{22}$

Consistent with his beliefs, Childe was on the editorial boards of Past and Present and The Modern (later Marxist) Quarterly, as well as the Society for Cultural Relations with the USSR. ${ }^{23}$ Decades after his death the arguments over Childe's Marxist beliefs continued; most of this was determined by the orientation of the writer, eg., pro- or anti- Marxist. Peace, who reviewed the debate, made what is probably the most reasonable assessment: Childe's Marxism was both provocative, arising from his determination to be different (eg, signing his name in Russian Cyrillic in letters to friends); and serious, in which he tried to apply historical materialism to his studies. ${ }^{24}$ It also changed over time from his early, naïve approach to the later, more nuanced, approach while distancing himself from Soviet Archaeology and influenced by issues such as anti-fascism. Some commentators believed that his suicide arose from the failure of his belief in Marxism following the Hungarian Revolution and Khrushchev's denunciation of Stalin. ${ }^{25}$ This view was rejected by

\footnotetext{
${ }^{22}$ Thomas N. Childe, Marxism And Archaeology. Dialectical Anthropology. Vol. 6, No. 3 (March 1982), pp. 245-252

${ }^{23}$ Sally Green. Prehistorian: A Biography of V. Gordon Childe. Moonraker Press; Bradford-on-Avon, pages 119-122.

${ }^{24}$ William Joseph Peace. The enigmatic career of Vere Gordon Childe: A peculiar and individual manifestation of the human spirit. Ibid, pages 29-37.

${ }^{25}$ Faulkner, N (2007). Gordon Childe and Marxist Archaeology. International Socialism. 116. pp. 81-106.
} 
Bruce Trigger, noting that while Childe was critical of Soviet foreign policy, he had an intellectual approach to Marxism that was separate from the state. ${ }^{26}$

Childe enjoyed travel, opera, theatre, fine food and good hotels; other pleasures being dining at the Athenaeum Club, keeping teddy bears, driving fast cars, reading poetry and playing bridge. He lived an otherwise spartan life and had never been known to have a relationship. Eccentric in dress and manner, Childe's legendary scruffiness fronted a sartorial inelegance not far removed from the Chaplin tramp, associated with a swallowed mumble (probably due to a cleft palate) to give him the unmistakable aura of the mad professor. ${ }^{27}{ }^{28} \mathrm{He}$ liked to wear shorts, a battered broad-brimmed hat and cape, priding himself on how many years he could keep the same trousers. ${ }^{29} 30$

A poor lecturer with a high-pitched squeaky voice and a tendency to address the blackboard, Childe could be inspiring to students. ${ }^{31}$ Many recalled how shy he was, even to the point of rudeness. Contradicting those who described him as reclusive and detached, he became a celebrity on the television quiz show Animal, Vegetable,

${ }^{26}$ Bruce Trigger (1980). Gordon Childe: Revolutions in Archaeology. London: Thames \& Hudson, pages 166-167;

${ }^{27}$ Gathercole P. Gordon Childe: memories and affirmation. Antiquity December 2010. Volume 84, Issue 326, pp. 1177-1179

${ }^{28}$ S. Piggot, "The Dawn: and an Epilogue," Antiquity, vol. 32 (1958), p. 77.

${ }^{29}$ Davey CJ. George Ware Dixon: An unrecognised Australian student of Gordon Childe. The Artefact 2016 - Volume 39, pp. 15 - 29

${ }^{30}$ Max Mallowan. Mallowan's Memoirs, London, 1977, pge 235.

${ }^{31}$ Gathercole, P., 2003. Life at the Institute of Archaeology, 1952-54. Archaeology International, 7, pp.10-12. 
Mineral $?^{32}$ His many associates around the world enjoyed his wry wit and self-deprecation, but found something unknowable in his character.

Isobel Wilson makes the point that Childe was twice an outsider. First, he was an Australian and, second, he was ugly. It was marginality that led him to make an intensive study of the Danube basin because it was a substantial European geographical entity in comparison to the geographically marginal British Isles which was only a political entity.

How does Childe's marginality explain his final decisions? In the Australia in which he was raised, his background was anything but working class; his minister father would have been appalled by the designation. But Charles Childe's pedantic religiosity became a touchstone that Childe used to propel himself in the opposite direction. The adoption of Marxism ensured that the gap between them was too wide to bridge. Childe became a humanist very early and looked to politics as a means to change the world. This ended in failure, not least because of the 'red' label, leaving him despairing, if not disgusted, about the atavistic state of Australian politics. His move to the UK was an understandable reaction, where he again became marginalised. Again, his reaction was to turn it against antagonists by relishing his eccentric dress and behaviour. It may also explain his lack of interest in

\footnotetext{
${ }^{32}$ https://www.imdb.com/title/tt0247850/fullcredits/?ref_=tt_ov_st_sm: accessed 26 March 2020.
} 
Australian prehistory. Yet, in the long decades in the UK, Australia never loosened its hold; in the end, like Ulysses, he had to come home.

But times change. As for his work, the tides of theory that he had been so assiduous in promoting were already pushing back in; he had done his dash with the culture-historical endeavour. ${ }^{33} \mathrm{His}$ paradigm model of the past ended when $\mathrm{C}^{14}$ dating showed it to be an invented past. Radiocarbon dating posed a growing threat to his conclusions about Neolithic and Bronze Age Europe..$^{34}$ It was evident that he was wrong about the origins of agriculture and, unusually for a Marxist, ignored the role of conflict and warfare. Childe recognised this and realised that his work was finished; the game was up.

A few weeks before his death Childe sent his Oxford colleague Grahame Clark an article entitled Retrospect. He called it an autobiographical note, looking back on his career as a prehistoric archaeologist, the influences on him and his scholarship achievements. Published later in Antiquity, the editor wrote that Childe was a formative figure in creating the climate of thought about the past for those under 65 .

${ }^{33}$ Sherratt A. V. Gordon Childe: Archaeology and Intellectual History. Past \& Present, No. 125 (Nov., 1989), pp. 151-185.

${ }^{34}$ Childe worked with Frederick Zeuner, an early proponent of radiocarbon dating, but was sceptical about its reliability. He did not exclude its future use but this was at an early stage when it was still being tested and had not achieved universal acceptance. 
In 1980, W F (Peter) Grimes, Childe's successor at the Institute, relayed the following conversation and added his comments in a letter to the editor of Antiquity, published in March $1980^{35}$ :

G: What are you going to do when you retire?

C: I know a 2000-ft cliff in Australia. I intend to jump off it.

G: Good god! Why are you going to do that?

C: I have a horror of a prostate operation.

G: But surely thousands of men have had that and come out of it without difficulty?

He made no further comment and seconds later I got out of the car.

Childe knew his own mind, though he rarely - very rarely - revealed it in personal matters.

Childe's subsequent conduct seems to me to be consistent and in some respects shrewd. Though there are disturbing features about it I believe that he did what he wanted

35 Editorial. (1980). Antiquity, 54(210), 1-6. It can be assumed that "G" refers to Grimes and "C" to Childe. 
Similar conversations were held with several people, including Professor S W Woolridge. ${ }^{36}$

It is unclear why Childe had such horror about prostate surgery. At his age, urinary frequency from an enlarged prostate was not uncommon. It is unknown whether he had medical confirmation of this (which, in any event, was potentially curable). More likely his response was to catastrophise a simple medical condition, a typical response in involutional (elderly) depression. An example of this is Hans Berger, discoverer of the EEG, who became convinced - incorrectly - that he had an incurable heart condition and hanged himself in $1940 .{ }^{37}$ His pessimism about making more contributions to prehistory and forgetting of details arose from the effect of the depression on his mood and cognitions.

Before his defenestration, Childe had also posted a letter to Peter Grimes. ${ }^{38}$ The letter's contents were not to be disclosed till January 1968. For reasons that are not clear, he added that the contents could even lead to libel actions. What followed was his apologia pro vita sua. He realised that he liked Australia even less than Europe, an indication of the loss of his ideals. He could not make any more useful contributions to prehistory and was forgetting details that he would remember in the

\footnotetext{
${ }^{36}$ Sidney William Wooldridge (1900 -1963) was a pioneer geomorphologist at King's College, London

${ }^{37}$ Kaplan RM. This Day in History: $6^{\text {th }}$ July 1924 Psychiatric Times, July 2020 (in press). Berger was unaware that he had been nominated for the Nobel Prize. ${ }^{38}$ Editorial. (1980). Antiquity, 54(210), 1-6. It was written from his accommodation at the Carrington Hotel, Katoomba. Oddly, it was dated the day after his death, possibly an unconscious error.
} 
past or list in his notebook. He could not resolve issues such as the Aryan cradle and - ominously - recognised the mounting evidence against his own theories.

His academic work complete, he had returned to say farewell to his native land. The situation was otherwise hopeless. Ahead lay only the dissolution of old age, helpless dependence and wretchedness. He had no wish to become a venerable but despised elder counsellor, was too dependent on his comforts to work and lacking the will power to face trips to the USSR or China. Added to this was a tendency to get ill. His pension would not allow a tolerable lifestyle so he would be a burden on society: Thus, I have always intended to cease living before that happens.

The British prejudice against suicide, Childe wrote, was irrational; in fact, this was what distinguished humans from animals. However, he did not intend to hurt his friends by flouting that prejudice. An accident on a mountain cliff may easily and naturally befall him. But he had enjoyed revisiting the Blue Mountains. "I have seen the Australian spring; I have smelt the boronia, watched snakes and lizards, listened to the 'locusts'. There is nothing more I want to do here... Life ends best when one is happy and strong." No, it was better to go now in full possession of mind. Peace, in his thesis, raises the interesting point that Childe only confided his suicidal intentions to conservative colleagues, rather than Marxist colleagues. 
Once the surprise over his death subsided, a curtain fell over his work for several decades. A workman-like biography followed. ${ }^{39}$ The nineties brought renewed attention. ${ }^{40}$ His Marxism was dismissed, the ideas on culture mostly regarded as untenable, but his formidable role in establishing prehistory as an independent discipline was acknowledged. ${ }^{41}$

Writers on Childe redivivus invariably discussed his personality, especially his eccentricity, dress and appearance. Some attributed the lack of intimate relationships to repressed homosexuality. He was, a colleague commented, an intellectual solitary. Another writer was quite certain that he was not only homosexual, but had Asperger's syndrome- ${ }^{42}$ This verdict is contradicted by many sources; eccentric in his ways Childe certainly was, but it is highly doubtful that he had Asperger's considering, amidst other features, his sociability. There is no way of knowing his sexuality, but it was never expressed towards men.

\footnotetext{
${ }^{39}$ Sally Green. Prehistorian: A Biography of V. Gordon Childe. Ibid.

${ }^{40}$ For example, see European Journal of Archaeology. Vere Gordon Childe - 50 years after. (Volume 12, No. 1-3, 2009.

${ }^{41}$ See: Gathercole P. Gordon Childe: memories and affirmation. Antiquity; Dec 2010; 84, 326; Goody J. Gordon Childe, the Urban Revolution, and the Haute Cuisine: An Anthropo-Archaeological View of Modern History. Comparative Studies in Society and History. Vol. 48, No. 3 (Jul., 2006), pp. 503-519; Brothwell D. Childe, his student, and archaeological science: An epilogue. European Journal of Archaeology Vol. 12(1-3): 193-202.

${ }^{42}$ Brothwell D. Childe, his student, and archaeological science: An epilogue. European Journal of Archaeology Vol. 12(1-3): 193-202.
} 
After all this time, what is to be made of the death of Gordon Childe? The views expressed about the last months before his death were generalisations based on second-hand information, leading to myths and misunderstandings. A careful look at the literature provides a more nuanced picture.

Much is made of his generosity in retiring a year earlier to allow his successor to settle into the job. Another explanation is that the mental pendulum - to go on, or to end his life - was spending more time in the distaff side. Returning to Australia on 14 April 1957 (his $65^{\text {th }}$ birthday), those whom he knew saw only positive features. ${ }^{43}$ He was reunited with Herbert and Mary-Alice Evatt ${ }^{44}$, his friends for decades. Staying with Eve and James Stewart at Mount Pleasant, he became friendly with Laila Haglund. ${ }^{45}$ She found him shy at first, but entertaining as he warmed to her, possibly because she was not aware of his intellectual prestige. He liked her smoking a pipe (as he did) and tried (unsuccessfully) to show her how to clean it with a grass straw. He told her of his enjoyment of the landscape. His death came as a shock and she found it hard to accept that he had committed suicide, stating "It is time this myth about Gordon Childe's suicide was knocked".

\footnotetext{
${ }^{43}$ Childe may not have been aware, but he was again placed under surveillance by the Department of Defence, an indication of how long the Marxist stigma followed him. William Joseph Peace. The enigmatic career of Vere Gordon Childe: A peculiar and individual manifestation of the human spirit. PhD Thesis. Columbia University, 1992, page 15.

${ }^{44} \mathrm{H}$ V 'Doc' Evatt was a leading Australian legal and political figure who played a part in the establishment of the United Nations. Attempts to find a link between their shared name of 'Vere' have not been successful.

${ }^{45}$ Editorial. Antiquity, July 1979, pgs 85-87.
} 
During the five months he was in Australia, Childe was certainly not inactive, completing several papers and his book The Prehistory of European Society. ${ }^{46} \mathrm{He}$ gave lectures at the Australian National University and in Melbourne, scandalising the audience with his denunciation of Australian suburban life in comparison to the ancient culture of Iceland. ${ }^{47} \mathrm{He}$ said he had returned to Australia to visit 'remembered scenes and old friends'. ${ }^{48}$

He was appalled by Australia's urban sprawl and cultural backwardness (Broken Hill being an honourable exception). This added another factor to his mood: failure of the idealistic belief that he could regain some of the nostalgic pleasure of his upbringing in his native land. Peter Gathercole, who organised the Melbourne talk, was told of his sadness at the death of Sean O'Riordain (excavator of Tara), another loss that weighed on his mind and likely to affect thoughts about his future. The death of a fellow Marxist prehistorian, O G S Crawford, also upset him. ${ }^{49}$

Childe left for Sydney, where he was guest of honour on the ABC. He had long discussions with the Stewarts about archaeology and plans for his research on the geology of the Blue Mountains. Eve Stewart felt he was enjoying

\footnotetext{
${ }^{46} \mathrm{~V}$ Gordon Childe. The Prehistory of European Society . Spokesman Publishers, Reprint edition (January 12, 2009).

${ }^{47}$ Mulvaney J. From 'The Dawn' to Sunset: Gordon Childe in Melbourne, 1957.

Australian Archaeology, No. 30 (Jun., 1990), pp. 29-32

${ }^{48}$ Fitzpatrick B. Meanjin, December 1957, page 424.

${ }^{49}$ Mulvaney J. ibid. Strangely, Crawford's death is listed as 28 November 1957, after Childe's death.
} 
retirement, free of academic commitments. He wrote enthusiastically to them between April and October. They were very fond of him and remembered the last visit two days before his death. When he left, he was cheerful and looking forward to returning.

Eve Stewart believed that he had gone out before breakfast on a hot day, taken off his coat and the heat, combined with an empty stomach, caused him to over-balance from a giddy turn. ${ }^{50}$ As soon as they learned the tragic news, James Stewart phoned Mrs Clift, the secretary of the Carrington Hotel, where Childe stayed. He had taken a taxi to Govett's Leap with instructions to the driver either to wait or return to take him to the Carrington for lunch. He intended to take the afternoon train to Bundanoon. When he did not arrive at the meeting place, the taxi driver went looking for him. ${ }^{51} \mathrm{He}$ found his coat on the edge of the cliff, with pipe and spectacles on top of it, and the compass on the rock beside it. The driver, who believed it was an accident, contacted the police who phoned to ask her whether he could have suicided, which she denied.

These opinions notwithstanding, the earlier conversation and letter to Grimes illustrates the extent of Childe's depression. He gave clear indications of his intention to kill himself by jumping off a cliff in Australia. Not forsaking the ideology that had motivated him, it was only his conservative peers that he told of his

${ }^{50}$ Editorial. Antiquity, July 1979, pgs 85-87.

${ }^{51}$ Archaeologist crashes down cliff to death. Canberra Times, 21 October 1957, page 1. 
intentions; Marxist colleagues were spared. Was this because suicide was antithetical to those beliefs? Marx, in a long forgotten piece ${ }^{52}$, attributed suicide to bourgeois oppression, which would not apply to Childe. To be a Marxist meant rejecting the label of alienation. Even if this did not apply to Childe, his strong identification with the cause would have excluded suicide as an acceptable solution. Viewed, however, in the terms put forward by Durkheim, it was a classic case of egoistic suicide.

The terms in which Childe viewed his situation were melancholic, if not morbid, indicating his loss of perspective. The closing lines of his letter were both prescient and ambiguous. He did not wish to hurt his friends by flouting the prejudice against suicide; however, a fall off a mountain cliff was quite possible. In short, his intention was to provide an escape clause. Like so many suicides, there would be a reverberating rationalisation of the pros and cons that eventually led only one way: down a path from which there was no exit.

In his $65^{\text {th }}$ year, Gordon Childe became depressed. We have no way of knowing what caused this. One factor that could have influenced this was the death of his mother, to whom he was very close, when he was 18 - a recurring issue in adults who later become depressed. If we shall not know whether he was constitutionally predisposed to depression, it made him focus inexorably on the negative aspects of

52 https://ethicsofsuicide.lib.utah.edu/selections/karl-marx/; Accessed on 16 April 2020. 
his life; the positive aspects - his great intellectual achievements and academic recognition, the many friends he had, the pleasures, small and big, that he always enjoyed and had kept him going - were all swept away. There was loss of memory, lethargy and reduced motivation. The preoccupation with minor illnesses, if not prostate problems, reflected somatic preoccupations. His expectations of the land he left so long ago was were not fulfilled. The cheerfulness witnessed by those he contacted was not faked. For the melancholic, once the final decision to suicide is made, there is an improvement in mood; ahead lies only certainty, control and final resolution.

John Davies Evans ${ }^{53}$ wrote, "With his post (resigning from the Institute) he gave up, quite literally, his reason for living". ${ }^{54}$ There was also a sense of intense loneliness; in Peter Gathercole's words, "He remained to the end quite unreconciled to his bachelorhood"..$^{55}$

It was the saddest end for a unique individual who deserved so much more in his life.

${ }^{53}$ Director of the London Institute from 1975.

5416 J. D. Evans, "No. 1: The First Half-Century - and After", Bull. Inst. Archaeol., xxiv (1987), pp. 1-25.

${ }^{55}$ Gathercole, "Gordon Childe: Man or Myth?", Antiquity, Ivi (1982), p. 198. 